\title{
Conscientious objection in health care
}

\author{
Josef Kuře
}

\begin{abstract}
The paper deals with conscientious objection in health care, addressing the problems of scope, verification and limitation of such refusal, paying attention to ideological agendas hidden behind the right of conscience where the claimed refusal can cause harm or where such a claim is an attempt to impose certain moral values on society or an excuse for not providing health care. The nature of conscientious objection will be investigated and an ethical analysis of conscientious objection will be conducted. Finally some suggestions for health care policy will be proposed.
\end{abstract}

Keywords: bioethics, conscience, health care, objection, reservation, right

\section{Introduction}

Protection of rights to act in accordance with one's conscience, and to decline participation in activities offensive to conscientious convictions, is recognized as a basic human right. Freedom of conscience is protected by constitutional and human rights in most European countries. A refusal of duties based on conscientious reasoning should be respected in democracies. One of the ways of exercising this human right is conscientious objection. The paper focuses on conscientious objection in health care, addressing the internal problem with the scope of refusal, difficulties of verification which appear in many situations when health care is refused on a conscientious basis (conscientious reasoning can be very broad), and possible ideological and political agendas hidden behind the right of conscience where the claimed refusal is not a genuine personal act of conscience but rather an attempt at cultural conquest, a strategy to produce obstruction and to impose certain moral values on society.

Conscientious objection also creates further ambivalence where public health care is warranted by the state. Then the state has make sure that all kinds of health care treatments allowed by law are widely accessible to all those who need them or who want to get them. Legitimate refusal of health care or refusal based on institutional tolerance of conscientious objection can also lead to harm to patients, prompting the question of professional and institutional responsibility and to the consequent issue of liability. This would create a "conscience creep in which all behaviour becomes acceptable" (Cantor, 2009, p. 1485).

Another issue is discrimination of the objector (e.g. reassigning the employee who claimed conscientious objection to a different department) and of those who did not object but who also were not privileged at the same time. From the organizational point of view, conscientious objection means to treat people differently, on unspecified grounds since the legislation of the right of conscience usually does not provide a statutory definition of conscience, the scope and the examination of conscientious objection which, by definition, cannot be objectivized.

\section{Background}

Conscientious objection, being an old phenomenon, as a right, however, appears only in societies that take individual persons and their autonomy seriously. Nevertheless, conscientious objection and the provision of a special category for conscientious objectors as a tool of the public body only became a burning issue since the First World War in the form of conscientious objection to military service (Churchill, 1996). Since then, it has been adopted within health care (primarily abortion and contraception) (Dooley, 1994; Dresser, 
2005; Wicclair, 2006). Conscientious objection can be found in all other areas of public life such as education or services (Morrison, 2014). Generally conscientious objection can be based on the grounds of freedom of thought, conscience, or religion. The relevance of these freedoms is given by human rights; conscientious exemption has been incorporated into constitutional and human rights systems (Noone, 1993).

Historically, conscientious objection in health care was based on religious grounds. The current versions of conscientious objection in health care are supported not only by religious reasons, claiming primarily freedom of thought or freedom of conscience rather than religious freedom. Nevertheless, the most frequent reason given for conscientious refusal is religious belief. However non-religious persons - atheists, agnostics and those who do not affiliate themselves with any organized religion - also have a conscience and they may claim conscientious objections on the ground of their conscience-based world view. In a pluralistic society, conscientious refusal can be based on a wide range of justifications, not only on religious ones. This can be illustrated using examples of vaccination (parental decision) or moral problems with certain health care procedures (health care professionals' decision) such as treatment of people with transmittable diseases (e.g. AIDS) or aggressive patients. An increasing number of health care professionals justify their refusal in such situations on nonreligious grounds, referring to general human values such as dignity or mercy and to their conscience rather than to their religion.

At present conscientious objection in health care does not cover the two traditional issues namely abortion (which affects mainly physicians and nurses) and contraception (where beside physicians also pharmacists are involved) - (Anderson, 2006) only. There are many other issues that can raise conscientious objection; among them are the following: treatments in reproductive medicine such as gamete donation, in vitro fertilization, freezing of gametes or embryos, pre-implantation genetic diagnostics, assisted reproduction for lesbian and gay couples, surrogate motherhood, and professional participation in all those procedures (morally evaluated as cooperatio in malum), prisoner interrogation, capital punishment, treating drunk patients, genetic testing and counselling, sterilization, transgender treatment, end-of-life care (medical futility, withholding and withdrawing treatment, terminal sedation, terminal weaning, artificial nutrition and hydration, administrating extreme doses of opioids, overdosing by opiates, euthanasia, assisted suicide) (Campbell, Hare \& Matthews, 1995; Schaupp, 2014; Rich, 2015).

The contemporary technical questions "Can we...?" (e.g. Can we provide even medically futile treatment to the terminally ill patients?) which are regularly answered "Yes, we can." can be transformed into "Should we...?"questions. The answers to those "Should we...?" questions have something to do with medically appropriate treatment and mostly with physicians' conscience. On the top of that, the changed medical paradigm whereby patient autonomy has become the dominant principle, has to be considered. Consequently, the physician is often regarded as a "health salesman or serviceman" who is offering health services and whose primary task is to fulfil the autonomous preferences of his/her client who is, in fact, a patient. Under such conditions and circumstances a new focus on the conscience of the individual health care professional is greatly needed. However, a provision for conscientious objection is a feature of "considerable sophistication in a political community" (Cohen, 1968, p. 269). Conscientious objection fits not only into a framework of human rights, tolerance and democracy but also into a framework of individualized societies with their emphasis on the value of individual preferences and autonomous choices (Lawrence, 2014). Conscientious objection can also become a manifesto of a social movement (HarriesJenkins, 1993). 


\section{Conscientious objection as a concept}

Conscientious objection is a right of health care professionals to refuse to conduct specific procedures or to decline participation in such procedures they believe to be against their conscience or against their religious moral code, and therefore immoral. Conscience claims of physicians, nurses and other health care personnel relate to moral issues that affect their individuality, identity and integrity. Conflicts of conscience usually arise in health care "because people regard as unethical some role obligation or official order that descends from a hierarchical structure of authority" (Beauchamp \& Childress, 2001, p. 38). The right of conscience protects a person from mandatory participation in an activity which collides with the fundamental values of that individual. Since patient autonomy has become the dominant principle in medical ethics, the right to conscience of health care professionals has been challenged (Orr, 2010).

Historically, there is a long tradition of subjective moral judgement in medicine. The normative provision has been set from the outset in the Hippocratic Oath: "I will prescribe regimens for the good of my patients according to my ability and my judgement" (Welfare \& Carter, 2007, p. 245). A physician's ability and judgement are necessarily subjective measures for medical decision making. At present, the most relevant and influential ethical normative statement is included in the International Code of Medical Ethics: "A physician shall be dedicated to providing competent medical service in full professional and moral independence, with compassion and respect for human dignity" (WMA, 2006). This statement delineates independence of physicians' values should they differ from that of their patients; the free exercise of conscience is guaranteed for the medical profession by the normative ethics of the WMA. The WMA later proclaimed professional autonomy and clinical independence as an essential principle of medical professionalism: "Individual physicians have the freedom to exercise their professional judgment in the care and treatment of their patients without undue influence by outside parties or individuals" (WMA, 2008).

There are several legal provisions, concerning human and civil rights, which protect conscience and its autonomy. The first article of the Universal Declaration of Human Rights (UN, 1948) states: "All human beings are born free and equal in dignity and rights. They are endowed with reason and conscience..." Article 18 of the same declaration affirms that "everyone has the right to freedom of thought, conscience and religion." A similar statement can be found in Article 18 of the International Covenant on Civil and Political Rights (UN, 1966): "Everyone shall have the right to freedom of thought, conscience and religion." The whole article deals predominantly with religious freedom. The Charter of Fundamental Rights of the European Union (2000) adopts a similar provision in Article 10: "Everyone has the right to freedom of thought, conscience and religion... The right to conscientious objection is recognised, in accordance with the national laws governing the exercise of this right." The Charter presupposes that the member states specify the scope and conditions of this right. The most specific European regulation is the Resolution 1763 (The Right to Conscientious Objection in Lawful Medical Care) adopted by the European Council in 2010 which limits the conscientious refusal to "abortion, the performance of a human miscarriage, or euthanasia or any act which could cause the death of a human foetus or embryo" solely (Campbell, 2011). The right to conscientious objection is an important freedom, however those who invoke this right "must show the same respect for the other's rights and freedoms as they require for their own" (Dickens, 2009a, p. 97).

\section{Ethics of conscientious objection}

The moral ambivalence of conscientious objection lies in the compatibility of conscientious objection understood as a human and constitutional right with the professional duties of a 
health care provider. There is, on the one hand, personal attitude based on personal values and views (personal beliefs), on the other hand, there is a standard of treatment within health care and obligations of health carers (professional duties) (Rich, 2015). Conscientious objection is the right to exercise freedom of conscience and of religion which coincides with unhindered access to health care. In public health care systems, it is an obligation of a state to assure that the right to health care is not diminished or threatened. It is not solely the issue of refusal of a particular health care treatment, but also an issue of medical indication for such a treatment, an issue of providing information about a particular treatment (as a necessary base for informed consent or dissent), and an issue of referring a patient to another health care professional who does not object to providing a particular treatment (May \& Ausilio, 2009). So the scope of activities which may fall under conscientious objection is much broader as is usually discussed. Conscientious objection does not affect only refusal of a treatment as a direct activity of a health care professional but also different levels of participation in such treatment (providing information, counselling, examination, assistance, diverse level of participation in the treatment, referring to a colleague who does not object). Conscientious objection has to be reflected on the individual level (physician $A$ refuses treatment $B$ to a patient $C$ ), but also on the societal level where a conflict arises between society and the health care profession.

There are two basic questions, namely if conscientious objection is compatible with health care profession at all, and if this is the case, to what extent and under which criteria is conscientious objection compatible with the profession (e. g. medical profession) (Dickens, 2009a; Magelssen, 2012). With regard to the first question, three different answers can be found. They can be formulated in the form of the following thesis: 1) Conscientious objection is incompatible with the medical profession. 2) Conscientious objection has to be respected absolutely. 3) Conscientious objection is compatible with the medical profession to some extent only and specific regulative provision limiting the refusal has to be in place.

The first thesis is supported by Julian Savulescu who holds conscientious objection as fundamentally incompatible with the medical profession. He gives the following reasons for his position: inefficiency and inequity, inconsistency, physicians' commitment, and discrimination (Savulescu, 2006, p. 295). Savulescu emphasizes that conscience can be "an excuse for vice or invoked to avoid one's duty. When the duty is a true duty, conscientious objection is wrong and immoral. When there is a grave duty, it should be illegal" (Savulescu, 2006, p. 294). Personal duty and professional responsibility is preferred to personal values. Personal conscience is separated from professional attitude. Similarly religious identity and professional identity has to be detached. In his view people who "are not prepared to offer legally permitted, efficient, and beneficial care to a patient because it conflicts with their values" should not become doctors (Savulescu, 2006, p. 294). Moreover "doctors who compromise the delivery of medical services to patients on conscience grounds must be punished through removal of [their] licence to practise" (Savulescu, 2006, p. 296). Savulescu argues that a "doctor's conscience has little place in the delivery of modern medical care" (Savulescu, 2006, p. 296). Personal values are important, but "they should not influence the care an individual doctor offers to his or her patient" (Savulescu, 2006, p. 297). Physicians are public servants and they "must act in the public interest, not their own" (Savulescu, 2006, p. 297). Savulescu admits conscientious objection under three conditions (Savulescu, 2006, p. 296): a) Sufficient doctors are willing to provide the service; b) Conscientious objectors must ensure that their patients are aware of the care they are entitled to and refer them to another professional; c) Conscientious objectors who compromise the care of their patients must be disciplined.

However, his argument is not compatible with the whole tradition of medical ethics and with the contemporary emphasis of many medical associations, including the WMA, on 
physician's conscience. Savulescu finally withdraws any personal responsibility of the medical professional. To be a good physician is identical with fulfilling professional duties; consequently physicians would become automatons instead of moral agents (Asch, 2006).

The opposite thesis, namely the thesis of conscience absolutism is held usually by different religious fundamentalists and, paradoxically, by those who understand medicine as a freemarket business - so it is up to the individual physician to state under which conditions he/she is selling his/her medical products and/or services. Conscientious objection understood as an absolute right can be claimed not only by individuals but by health care institutions as well. Then it is not only a physician's right to refuse treatment, moreover it is his/her duty to refuse treatment. Christopher Kaczor argues that there is no moral right to do what we have a moral duty not to do (Kaczor, 2012). Then religious individuals and institutions have a crucial obligation to refuse to provide or to refer for medical treatment which is "deeply sinful" (Cherry, 2012). Conscience absolutism is not compatible with democratic value pluralism.

The third thesis is based on the conviction that moral integrity is an important value for the individual, deserving protection (Pellegrino, 2008). The authors who hold the middle-ground position on conscientious objection request legal protection for such refusal, simultaneously stressing the physician's obligation to provide the necessary information in order to prevent any harm and to refer the patient accordingly. So they acknowledge the right of refusal as a value of personal integrity. ${ }^{1}$ This right should by guaranteed in a democratic liberal society as its constitutive element and as respect for human rights. However it has to be limited in order to avoid an unjustifiably broad interpretation of freedom of conscience. While there is no doubt as to the existence of conscientious objection in health care, there are some necessary conditions that must be met for the legitimate exercise of the right to conscience. The primary condition is the lack of significant harm posed to others. The right to conscience can be exercised only if carrying out this right does not pose significant harm to others (a balance between the right of an autonomous choice of health care professionals and individual harm of patients and social harm to society). The exercise of this right has to be based upon the fundamental values of the person claiming such a right. The base for making a claim for conscience should be founded on sincerity and the strength of the individual's beliefs, which of course remain of a subjective nature. The right to conscience should be weighed against professional obligation to respect the autonomy of the patient and to avoid discrimination (May, 2003). If the conscientious refusal of health care professionals is affirmed by law, appropriate legal provisions should be put in place in order to prevent social harm and to harmonize the right to access to health care procedures and the right of caregivers to manifest their moral autonomy. However, laws in some jurisdictions problematically abuse religious conscience by granting excessive rights to refuse care (Dickens, 2009b). West-Oram and Buyx recently argue that "some rights to freedom of conscience asserted by health care providers are excessive in liberal societies, incompatible with liberal norms of pluralism and personal freedom, and impose unjustifiable costs on both individual persons, and society" (West-Oram \& Buyx, 2016, p. 236).

The proportionality and reciprocity is an important criterion to weight individual rights (conscientious objection) and social rights (access to public health care). It is a significant political obligation to assure both of them. The scope of refusal has to be specified and limitations of conscientious objection have to be clearly demarcated. And only within this demarcation conscientious objection can be claimed. The limitation also includes duty of information and referral. It means that moral absolutism which refuses all activities including providing information and referring to another professional collides with the principles of reciprocity and with social values such as access to lawful health care. Such referral would be

\footnotetext{
${ }^{1}$ Mark Wicclair calls this position "compromise" (Wicclair, 2011, pp. 32-86). I'm avoiding using this term, since attitudes such as respect for human right cannot be properly called "compromise".
} 
not legitimate objection but illegitimate obstruction. The negative consequences which refusal has for patients (inhibition of lawful health care) have to be assumed by the health care institution or by the state, not to stop access for lawful health care. Patients should not bear the burden caused by refusal. Objectors have to be willing to accept part of such problems, risks and burden. The minimal willingness of objectors to share those inconveniences is tolerance to indirect and remote participation (complicity) in the refused treatment (e. g. providing information).

The internal logic of conscience absolutism would clash with some basic values of ideologically neutral states such as pluralism, tolerance and governance of law. Conscientious objection can be transformed into obstruction, cultural oppression and social discrimination (Wicclair, 2011, pp. 87-124). Conscientious objection cannot become a tool of manipulation of others. Therefore, conscientious objection is only acceptable in a democratic society to some extent. By admitting conscientious objection no discrimination can be generated; while the right of health care professionals to refusal is acknowledged, the rights of patients to selfdetermination have to be guaranteed - and part of their rights to lawful treatments is the right to information about all those legal forms of health care.

Recent debates on conscientious refusal have shown two aspects of the right to freedom of conscience. On the one hand, the right to conscience (as a human right) has severe implications for health care. Any health care provider is entitled to claim the right to act in accordance with his/her conscience. On the other hand, conscience clauses have been criticized as "objector legislation" or "abandonment laws" that cause new forms of discriminatory practices (Anderson, 2006; Dickens, 2009b; Cantor, 2009; Wicclair, 2011, pp. 203-230). Conscientious objection can be claimed by anybody, not only by those persons who have religious or philosophical reasons to do so. Since there are no means to verify such conscientious claims (How could one verify or control conscience in a democratic society?), authentication of such claims would be not feasible. Insincere claims, based not on conscience but on other grounds such as self-interest, dissimulation or hypocrisy, or too broad a scope of objection, would become unavoidable. Therefore, some authors request medical tribunals as a reasonable platform for evaluation of conscientious objection (Card, 2016). Other authors hold this verification as not feasible (Cowley, 2016) or as a new form of medical paternalism. Not surprisingly, attempts to regulate the rights of one group of citizens in a nonstandard way, at the expense of other citizens, faces criticism because the principle of equality would be affected. Since the scope of conscientious refusal has to be legally limited (Jarosch, 2009), also with regard to coherence, in many cases, conscientious objection will be based on certain recognizable religious normative traditions, becoming as if a religious objection a form of religious freedom. So from freedom of conscience, we would land at freedom of religion which was the original base for refusal to abortion and contraception.

\section{Conclusion}

Freedom of conscience as a human right arises only in societies that take autonomy of an individual seriously. Conscientious objection in health care is not absolute. The value of personal integrity has to be balanced with the right to lawful health care. So the scope of such refusal has to be specified and the limits for conscientious objection have to be set; exercise of this right has to be regulated. Otherwise conscientious objection would lead to obstruction, discrimination and cultural conquest. Conscientious objection is acceptable only under the condition of moral plausibility or religious rationale. Conscientious objection in health care may be claimed if sufficient health care professionals are willing to provide lawful treatment and if the burdens rising from such refusal to patients, colleagues and health care institutions are acceptably small. Conscientious objectors must ensure that their patients are aware of the care and treatments they are entitled to and refer them to another professional. The health care 
provider must ensure that access to health care is not restricted or threatened and that no harm to patients will result from the refusal. The values behind conscientious objection influence the decision of the objector but not the decision on what kind of health care system to deliver and what kind of treatment to provide in public health care. Conscientious objection cannot be based on an excessively and unreasonably broad definition of complicity and freedom of conscience. Otherwise it would result in a rule that knows no bounds.

Josef Kuře, philosopher and bioethicist, is Head of the Department of Medical Ethics, Masaryk University, Brno (Czech Republic).

\section{Corresponding author:}

Josef Kuře, Department of Medical Ethics, Masaryk University, Kamenice 5, 62500 Brno, Czech Republic

Email: jkure@med.muni.cz

\section{References}

ANDERSON, R. M. et al. (2006): Pharmacists and Conscientious Objection. In: Kennedy Institute of Ethics Journal, 16(4), pp. 379-396.

ASCH, A. (2006): Policy and Politics: Two Cheers for Conscience Exceptions. In: Hastings Center Report, 36(6), pp. 11-12.

BEAUCHAMP, T. L. \& CHILDRESS, J. F. (2001): Principles of Biomedical Ethics. Oxford $\&$ New York: Oxford University Press, $5^{\text {th }}$ edition.

CAMPBELL, C. S., HARE, J. \& MATTHEWS, P. (1995): Conflicts of Conscience: Hospice and Assisted Suicide. In: The Hastings Center Report, 25(3), pp. 36-43.

CAMPBELL, M. (2011): Conscientious Objection and the Council of Europe: The Right to Conscientious Objection in Lawful Medical Care. In: Medical Law Review, 19(3), pp. 467475.

CANTOR, J. D. (2009): Conscientious Objection Gone Awry - Restoring Selfless Professionalism in Medicine. In: New England Journal of Medicine, 360(15), pp. 1484-1485.

CARD, R. F. (2016): In Defence of Medical Tribunals and the Reasonability Standard for Conscientious Objection in Medicine. In: Journal of Medical Ethics, 42(2), pp. 73-75.

CHERRY, M. J. (2012): Conscience Clauses, the Refusal to Treat, and Civil Disobedience Practicing Medicine as a Christian in a Hostile Secular Moral Space. In: Christian Bioethics, 18(1), pp. 1-14.

CHURCHILL, R. P. (1996): Conscientious Objection. In: D. K. Wells (ed.): An Encyclopedia of War and Ethics. Westport, CT: Greenwood Press, pp. 99-102.

COHEN, C. (1968): Conscientious Objection. In: Ethics, 78(4), pp. 269-279.

COWLEY, C. (2016): Conscientious Objection and Healthcare in the UK: Why Tribunals are not the Answer. In: Journal of Medical Ethics, 42(2), pp. 69-72.

DICKENS, M. B (2009a): Conscientious Objection and Professionalism. In: Expert Review of Obstetrics \& Gynecology, 4(2), pp. 337-347.

DICKENS, M. B (2009b): Legal Protection and Limits of Conscientious Objection: When Conscientious Objection is Unethical. In: Medical Law, 28(2), pp. 337-347.

DOOLEY, D. (1994): Conscientious Refusal to Assist With Abortion. In: British Medical Journal, 309(6955), p. 622.

DRESSER, R. (2005): Professionals, Conformity, and Conscience. In: The Hastings Center Report, 35(6), pp. 8-9.

EUROPEAN UNION (2000): Charter of Fundamental Rights of the EU. [online] [Retrieved November 7, 2016] Available at: http://ec.europa.eu. 
HARRIES-JENKINS, G. (1993): Britain: From Individual Conscience to Social Movement. In: C. C. Moskos \& J. W. Chambers (eds.): The New Conscientious Objection: From Sacred to Secular Resistance. New York \& Oxford: Oxford University Press, pp. 67-79.

JAROSCH, J. P. (2009): Finding Space for Opposing Consciences: Rehabilitating the Moral Marketplace. In: Northwestern University Law Review, 103(3), pp. 1461-1493.

KACZOR, C. (2012): Conscientious Objection and Health Care. In: Christian Bioethics, 18(1), pp. 59-71.

LAWRENCE, R. E. (2014): Conscientious Objection and Its Social Context. In: Journal of Medical Ethics, 40(9), pp. 613-614.

MAGELSSEN, M. (2012): When Should Conscientious Objection be Accepted. In: Journal of Medical Ethics, 38(1), pp. 18-21.

MAY, T. (2003): Right of Conscience. In: S. G. Post (ed.): Encyclopedia of Bioethics. New York: Thomson, $3^{\text {rd }}$ edition, vol. 1, pp. 517-520.

MAY, T. \& AUSILIO, M. P. (2009): Personal Morality and Professional Obligations: Rights of Conscience and Informed Consent. In: Perspectives in Biology and Medicine, 52(1), pp. 30-38.

MORRISON, K. (2014): Homeschooling as an Act of Conscientious Objection. In: Journal of Thought, 48(3-4), pp. 33-56.

NOONE, M. F. (1993): Legal Aspects of Conscientious Objection: A Comparative Analysis. In: C. C. Moskos \& J. W. Chambers (eds.): The New Conscientious Objection. New York \& Oxford: Oxford University Press, pp. 177-195.

ORR, R. D. (2010): Medical Ethics and the Faith Factor: The Endangered Right of Conscience. In: Ethics \& Medicine, 26(1), pp. 49-54.

PELlEGRINO, E. D. (2008): The Philosophy of Medicine Reborn. Notre Dame, IN: University of Notre Dame Press, pp. 281-306.

RICH, B. A. (2015): Your Morality, My Morality: Conscientious Objection and the Standard of Care. In: Cambridge Quarterly of Healthcare Ethics, 24(2), pp. 214-230.

SAVULESCU, J. (2006): Conscientious Objection in Medicine. In: British Medical Journal, 332(7536), pp. 294-297.

SCHAUPP, W. (2014): Zwischen personal beliefs und professional duties: Weltanschaulichreligiöser Pluralismus als neue Herausforderung für das ärztliche Gewissen. In: F.-J. Bormann \& V. Wetzstein (eds.): Gewissen: Dimensionen eines Grundbegriffs medizinischer Ethik. Berlin \& Boston: De Gruyter, pp. 3-24.

UN (UNITED NATIONS) (1966): International Covenant on Civil and Political Rights. [online] [Retrieved November 7, 2016] Available at: www.un.org.

UN (1948): Universal Declaration of Human Rights. [online] [Retrieved November 7, 2016] Available at: www.un.org.

WELFARE, M. \& CARTER, J. (2007): The Foundation Programme: The Medics' Practical Guide to Thriving and Surviving. New York: Elsevier.

WEST-ORAM, P. \& BUYX, A. (2016): Conscientious Objection in Healthcare Provision: A New Dimension. In: Bioethics, 30(5), pp. 336-343.

WICCLAIR, M. R. (2011): Conscientious Objection in Health Care: An Ethical Analysis. Cambridge: Cambridge University Press.

WICCLAIR, M. R. (2006): Pharmacies, Pharmacists, and Conscientious Objection. In: Kennedy Institute of Ethics Journal, 16(3), pp. 225-250.

WMA (World Medical Association) (2006): International Code of Medical Ethics. [online] [Retrieved November 7, 2016] Available at www.wma.net.

WMA (2008): Declaration of Seoul on Professional Autonomy and Clinical Independence. [online] [Retrieved November 7, 2016] Available at www.wma.net. 